NBER WORKING PAPER SERIES

DOES MONETARY POLICY AFFECT

REAL ECONOMIC ACTIVITY?: WHY

DO WE STILL ASK THIS QUESTION?

Benjamin M. Friedman

Working Paper No. 5212

\author{
NATIONAL BUREAU OF ECONOMIC RESEARCH \\ 1050 Massachusetts Avenue \\ Cambridge, MA 02138 \\ August 1995
}

This paper was prepared for a conference on "Monetary Policy in an Integrated World Economy" at the Kiel Institute of World Economics, June 21-22, 1995. I am grateful to Fernando Leforte for research assistance, to numerous friends and colleagues for useful suggestions, to John Taylor and other participants in the Kiel Institute conference for helpful comments on an earlier draft, and to the G.E. Foundation and the Harvard Program for Financial Research for research support. This paper is part of NBER's research program in Monetary Economics. Any opinions expressed are those of the author and not those of the National Bureau of Economic Research.

(C) 1995 by Benjamin M. Friedman. All rights reserved. Short sections of text, not to exceed two paragraphs, may be quoted without explicit permission provided that full credit, including () notice, is given to the source. 


\begin{abstract}
The predominant weight of the existing evidence suggests that the effects of monetary policy on real economic activity are systematic, significant, and sizeable. Yet questions remain, both about individual empirical results and, more broadly, about the different methodological approaches that researchers have used to investigate these effects. This paper addresses the conceptual issues that account for our continuing to ask whether monetary policy has real effects even though, at a certain level, we do "know" the answer. The paper's overview of theory and evidence suggests that much of the explanation for the continuing tug-of-war between research findings and subsequent questions in this area lies in two sets of limitations, one reflecting how economics conceptualizes behavioral processes and one reflecting how economics draws inferences from observed data.
\end{abstract}

Benjamin M. Friedman

Department of Economics

Littauer 127

Harvard University

Cambridge, MA 02138

and NBER 
Revised

July, 1995

\section{DOES MONETARY POLICY AFFECT REAL ECONOMIC ACTIVITY?: WHY DO WE STILL ASK THIS OUESTION?}

Benjamin M. Friedman*

Harvard University

Knowledge is of two kinds.

Samue 1 Johnson

There is, not infrequently, substantial dissonance between the stance that economists take in frontier research and what "practical" people -- business executives, for example, or government decision makers - - think about the same questions. The influence of monetary policy on real economic activity presents an interesting example, both for the importance of the subject itself and for the intellectual issues that account for the divergence. Few businessmen doubt that when their country's central bank pursues a tighter monetary policy, growth of output, employment and real incomes in their economy will abate for some time. Few central bankers doubt this connection either. (Whether or not they seek to exploit it in conducting policy is another matter.) By contrast, the focus of work that represents the frontier of new economic research is as much on whether monetary policy affects real activity as on how large such effects may be or how they come about.

Why does this gulf between "academic" research and "practical" thinking persist? Is this a case in which those academic thinkers whose views are at odds with conventional wisdom have developed a new perception of the facts that widespread opinion will eventually accept? (Most sciences offer numerous such 
examples.) Or have many academics somehow failed to comprehend what everybody else already knows? Or is there something else at work?

This paper's overview of theory and evidence describing the effects of monetary policy on real economic activity suggests that much of the explanation lies in two sets of limitations, one reflecting how economics conceptualizes behavioral processes and one reflecting how economics draws inferences from observed data. On neither account are researchers guilty of wrong-headedness, willful blindness, mere foolishness, or any of the similar intellectual failures of which practical people sometimes accuse thinkers whose views they either reject or misunderstand. These limitations are instead simply the constraints that inevitably hold back a science that is still in the early stages of its theoretical development and, moreover, that must make do empirically without conducting controlled experiments.

The relevant question for purposes of public policy is what to make of this state of epistemological affairs. Before one can meaningfully consider what a central bank should do, it is of course essential to know something about the likely consequences of its potential actions. Does monetary policy, after all, systematically affect production, employment and real incomes, or does it merely affect nominal magnitudes? If it has real effects, does it alter the composition of economic activity in addition to the aggregate level? Beyond the qualitative answers to such questions, what are the relevant magnitudes? And the associated timing? Doubts about the possibility of obtaining satisfactory answers to questions like these have sometimes led to the recommendation that central banks follow nonresponsive rules, like making one or another measure of money grow at a fixed rate over time, but even such seemingly simple policy rules can make sense only with specific knowledge of the relationships connecting the chosen money quantity to income, prices, and 
so on. It is impossible to implement even a "take no action" rule without knowing what observable price or quantity provides the benchmark for measuring the action not taken.

The nub of the matter, I believe, is what it means to "know" in this context. The dissonance between thought at the policymaking table (and in the business and financial world more generally) and thought at the research frontier reflects, in large part, the difference between two distinct senses of "knowing." As economics strives to evolve into a more exact science, researchers develop progressively more exacting standards of what it means either to know that a conclusion about economic behavior follows from the posited assumptions or to know that the comovement of observed phenomena represents cause and effect. From time to time, this ongoing advance in the exactitude to which researchers aspire will inevitably outpace the accompanying progress in the exactitude that they can achieve. All this is basically healthy, the outward sign of a robust discipline undergoing progressive intellectual evolution.

At the same time, the world of affairs places its own requirements on both public policymakers and private interests. Simply plunging ahead, rigidly oblivious of new thinking, clearly risks perpetuating sub-optimal (perhaps even counter-productive) policies well past the point where developments at the research frontier have shown their futility. But the frontier itself is constantly in motion, and neither central banks nor private businesses can alternately shut down and reopen as the evolving state of current economic theory and evidence sometimes falls behind and sometimes edges ahead of evolving standards for what that theory and evidence ought to be.

The theory and evidence reviewed in this paper suggest that economists do "know" that monetary policy systematically affects real economic activity -. at 
least we know this sufficiently to warrant making both monetary policy and private business decisions on that basis. Further, economists also "know" a fair amount about the incidence and timing of these effects: enough, for example, to warrant a clear preference for some kinds of monetary policy strategies over others, depending on the specific circumstances and objectives of the central bank making the policy.

What remains less well understood, even at this level of "knowing," is just what market processes are principally responsible for these real effects. This lacuna is an important one because central banks would be better able to carry out actual monetary policies if they knew more about the key aspects of the underlying economic behavior, and therefore could identify the specific prices and quantities that represent the most useful sources of information to guide their actions on a current basis. But not knowing more than we do about how the real effects of monetary policy come about does not constitute grounds for proceeding as if there were no such effects in the first place. It is not as if we were wholly in the dark.

Section I addresses issues of theory. The main focus is on the difficulty of modeling behavioral processes that account for generalized price stickiness, and especially on the difficulty of specifying dynamics that render prices rigid in the short run but flexible in the long run (and hence attribute real effects to monetary policy in the short run but not the long run). Section II addresses issues of identification and observability. Attention along both dimensions is on the difficulty of finding suitable empirical representations of monetary policy actions when, as is in fact the case, the prices and quantities that most naturally correspond to the relevant conceptual magnitudes are unobservable. Section III reviews recent empirical contributions bearing on whether monetary policy affects real activity, distinguishing three 
different methodological approaches that researchers have extensively used. Section IV briefly concludes.

The paper's object is to bring out significant conceptual issues that account for our continuing to ask this important question despite the conclusion that, at a certain level, we do "know" the answer. The approach throughout is therefore illustrative and interpretive, not to provide either details of specific models or a comprehensive survey. The question at issue is not how the real effects of monetary policy come about (addressing the "transmission mechanism" would require another paper), but whether monetary policy affects real activity and how we "know" that it does. 


\section{Theory}

Economists prefer simple models. Repeated experience clearly shows that progress in economic thinking is possible only with heroic simplification. The phenomena we study are sufficiently complex, compared to our primitive existing level of understanding, to preclude useful analysis of any but a small handful of different dimensions of economic behavior at a time. Even when the object of a new contribution is to analyze some aspect of behavior that previous work has held aside, either by explicitly assuming it to be invariant or by simply ignoring it altogether, the price paid for such an advance is often to assume away yet some other aspect of behavior that was regularly under study in previous lines of research. ${ }^{1}$ (As an illustration, consider the oxymoronic implications of "general equilibrium analysis of a pure exchange economy.")

The preference for simple models is relevant here because in the simplest economic models monetary policy does not affect any aspect of real behavior. When all markets clear instantaneously and without friction - - by the function of a posited Walrasian auctioneer, or some equivalent process that takes the auctioneer's place - money itself is simply a "veil" through which rational producers, consumers and investors naturally see. Because the central bank's power springs strictly from its monopoly over the supply of what constitutes a veil, nothing it does can influence real behavior. As the rich literature following Arrow and Debreu has amply demonstrated, this set of ideas may be simple but it is hardly simple-minded. Elaborate and at times subtle analysis of conditions under which Walrasian outcomes prevail has been, and remains, an important line of economic theorizing.

As Keynes observed, however, ". . . criticism of the accepted classical theory of economics has consisted not so much in finding logical flaws in its analysis as in pointing out that its tacit assumptions are seldom or never 
satisfied." 2 The only change, sixty years later, is that the progressive tendency of economics toward more formal analysis has left fewer of the relevant assumptions unstated, and so the entire enterprise has become more transparent. Nobody disagrees that Walrasian outcomes, including irrelevance of monetary policy for real activity, follow in a world characterized by Arrow-Debreu conditions. The challenge is to specify which of these conditions obtain and which do not, and to trace out the implications that follow from the resulting, more plausible, alternative set of assumptions.

What makes this challenge hard -. and, in particular, what inevitably leads research on monetary policy away from the desideratum of simplicity -. is the continuing presumption that Walrasian outcomes do follow in the fullness of time. Theoretical research has provided ample grounds to accept that whatever real effects monetary policy has may be persistent (because of effects on physical and/or human capital formation, for example), and empirically it appears that high rates of price inflation, sustained over some lengthy period, tend to imply lower ongoing rates of real growth. ${ }^{3}$ But even economists who argue that the real effects of monetary policy are highly persistent typically reject the notion that an economy's entire subsequent trajectory of real activity can be different merely because its central bank has acted differently during one finite period in its history. ${ }^{4}$

The challenge, therefore, is not merely to specify the non-Walrasian conditions under which monetary policy affects real activity but to do so in such a way that the resulting real effects do not persist indefinitely. Simply assuming that some price is rigid, or that some inequality constraint across quantities is binding, is insufficient. It is also necessary to specify the dynamics by which the relevant price becomes flexible, or the operative constraint is relaxed, over time. Dynamics have always been a weak point in 
economic theorizing, however, and dynamic models are certainly not always simple .

The longest-standing tradition in the effort to establish a satisfactory theoretical underpinning for real effects of monetary policy is generalized price rigidity (importantly including wages). As has long been recognized, assuming that prices are fixed immediately turns the central bank's power into a monopoly over the supply of a real commodity, and hence influence over that commodity's relative price, from which a variety of consequences for real behavior readily follow. But proceeding in this simple way would attribute real effects to monetary policy in the long run as well, and nobody believes that prices are permanently rigid anyway. What is needed is - again -. to specify dynamics that coherently connect the short run of price rigidity with the long run of price flexibility.

For example, when Sargent and Wallace (1975) demonstrated the invariance of real outcomes to anticipated monetary policy actions even in a context that superficially resembled a Hicksian IS-LM model, Fischer (1977) and Phelps and Taylor (1977) quickly pointed out that this conclusion rested on the assumption - unlike in the usual IS-LM model - of price flexibility. They made their argument, however, not by assuming simple price rigidity but by positing specific non-Walrasian price- (or wage-) setting processes that render relative prices at any given time subject to disturbances, including central bank actions, but allow these effects to dissipate over time. ${ }^{5}$ Non-Walrasian price setting based on ( $s, S)$-type limlts, as suggested by Caplin and Spulber (1987), has the same important pair of properties. Within the relevant limits a seller's price is rigid, but if the relevant disturbances follow well behaved stochastic processes, in time the price will change. "Menu cost" models, proposed by Akerlof and Yellen (1985) and Mankiw (1985), likewise impose 
non-Walrasian frictions on price setting and consequently admit non-Walrasian outcomes including real effects of monetary policy. But here too the rigidity is of finite life, and therefore so are the real effects of monetary policy. ${ }^{6}$

Given the ample development of models that apparently meet the requisite challenge, why is whether or not monetary policy systematically affects real economic activity still an open question for research? To be sure, much of the explanation is empirical (see Sections II and III below). But an important part too is that models working out the consequences of imperfect competition, market externalities, asymmetric information, learning, and other familiar impediments to Walrasian equilibrium inevitably fail the simplicity test. As long as economists prefer simple models, therefore, the idea of a world in which money is a veil will continue to have strong appeal - unless (until?) new research reveals how to capture the essence of these imperfections in suitably simple form.

This failure of simplicity is further compounded once the purpose of the theory in question is to provide some guidance to central banks on how to go about implementing monetary policy. There is a wide gulf separating the most general (and therefore simple) models in which monetary policy has real effects from the world in which actual central banks operate. Money is not actually necessary for making payments, and much of what is called "money" cannot be used to make payments anyway. Issuers of money are not the only suppliers of credit. In a world consisting of different countries, there are many different moneys, which may be more or less closely substitutable for one another. More puzzling still, even if the standard set of familiar market imperfections and resulting rigidities does make real economic activity depend on monetary policy, how can the quantitatively small actions that central banks actually take possibly exert meaningful effects on such large economies? Some other 
element is needed, and specifying that additional part of the story takes the resulting theory yet further away from simplicity. 7

To illustrate with an example, the United States is a $\$ 7$ trillion economy, with private wealth of approximately $\$ 21$ trillion. The Federal Reserve System conducts monetary policy mostly by buying and selling U.S. Government securities. There are $\$ 4$ trillion worth of these securities outstanding, and the volume of debt instruments that are plausibly close (though imperfect) substitutes for them -. including federal agency securities, corporate bonds, municipal bonds, commercial paper, negotiable bank certificates, and so on -. is another $\$ 7$ trillion. Including potential substitutes denominated in other currencies, the size of the market is still greater. How, then, can it be important to the market's supply-demand equilibrium if the Federal Reserve buys or sells an extra $\$ 1$ billion, or even $\$ 10$ billion, of these securities? Yet such is the scale on which the Federal Reserve conducts its open market operations.

Even to begin to answer this question is not only to leave simplicity behind but, indeed, to set off down a road that seemingly has no visible terminus: Whether the Federal Reserve buys $\$ 1$ billion or $\$ 10$ billion of government securities in any year makes little difference for the market supply of securities, but buying securities is how the central bank creates reserves, and $\$ 1$ billion versus $\$ 10$ billion is a (proportionally) very large difference for the supply of reserves. ${ }^{8}$ After all, in a world with a banking system, the commodity over which the central bank possesses a monopoly is not money itself but bank reserves. ${ }^{9}$ In a fractional reserve banking system, banks must hold reserves in proportion to their deposits. By varying the supply of reserves, the central bank can therefore affect the volume of deposits banks can create and hence the volume of credit they can extend, and changes in the 
supplies of money and credit in turn affect interest rates and asset returns more generally. Effects on real activity then readily follow.

But only some kinds of deposits are typically subject to reserve requirements. (In the United States, for example, reserve requirements apply only to transactions balances, which amount to less than one-fourth of the M2 money stock.) Restricting the supply of reserves therefore does not restrict banks' overall ability to create deposits. It merely constrains the composition of banks' deposits. Further, by getting customers to hold non-reservable deposits instead of reservable deposits, banks can therefore extend as much credit as they choose, irrespective of the supply of reserves. Is it plausible that depositors are so reluctant to hold one kind of deposit instead of another that the fluctuations in market interest rates commonly attributed to monetary policy are no more than what is necessary to induce banks' customers to make such changes?

Moreover, in countries with highly developed financial systems, banks are hardly the only source of credit anyway (nor the only issuers of many deposit-type instruments). Finance companies make short-term business loans, funding their asset positions by issuing bank-like liabilities to which no reserve requirements pertain. Open market investors, who likewise face no reserve requirements, buy securities representing packaged credits of all kinds, ranging from home mortgages to auto loans, credit card balances and even business loans. Medium- to large-size firms borrow not only in their home countries but from lenders around the world, and they also borrow directly in markets for tradable corporate obligations, including bonds and commercial paper. Are the real effects of monetary policy solely a matter of the small business borrowers who can obtain credit only from banks (in their home country) and whose obligations their lenders cannot package for resale? How 
large an effect can these small businesses exert on aggregate production and employment?

Attempts to address questions like these -- to show not only how monetary policy might affect real activity in a non-Walrasian but nonetheless highly idealized world, but also how it does so in a model more plausibly corresponding to the conditions of actual economies with well developed financial systems - - constitute the most active single focus of monetary policy research today. The specific issues recently under the most active investigation include the substitutability of one form of "money" for another, the substitutability of bank for nonbank sources of credit, the role of asymmetric information and incentive incompatibility in preventing credit markets from clearing, and the effect of quantity constraints on the behavior of credit-rationed producers and consumers. 10 Given the state of economic science, tracing these aspects of behavior from the level of the individual agent to consequences for the (money or credit) market as a whole, and then on to real economic activity, requires models that necessarily fail the simplicity test. The power of these models to be persuasive must therefore come from their ability to explain the observed data. As a result, the more research on whether monetary policy has real effects becomes research on how monetary policy has real effects, the more essentially empirical it becomes. 


\section{Observability and Identification}

Empirical evaluation requires observed data. Simply observing either individual behavior or market outcomes is not necessarily adequate, however. The prices and quantities actually observed must also correspond to those at work in the theory to be evaluated. The absence of this correspondence in practice is an ongoing and dominant theme in the empirical literature of monetary policy.

Observability. The most basic issue in this regard is that the prices and quantities to which standard theory most naturally points as key links between the central bank's actions and private agents' behavior are, in some cases, simply not observable. For example, many of the most straightforward models of real effects due to monetary policy describe either firms or households as responding to relative prices determined in financial markets: interest rates, exchange rates, capital asset prices, and the like. But while the existing theory of how firms and households respond to interest rates, for example, is mostly a theory about real interest rates, what is observable is typically a nominal rate. 11 Only in conjunction with some inference about (unobservable) expectations of future price inflation does the observed nominal interest rate imply the theoretically appropriate real rate. Similarly, most theories relating the behavior of either firms or households to capital asset prices -. for example, Tobin's model relating firms' investment behavior to the market price of capital - - also hinge crucially on the relationship between prevailing prices and (unobservable) expected future prices. Real exchange rates are more straightforward (although ambiguities of choosing the right price index remain), but only on a spot basis. Forward real exchange rates are subject to the same kind of complication that makes real interest rates unobservable, only more so because here what matters is expected future price inflation in two countries. 
Quantities can be unobservable too. After most familiar statistical relationships connecting one or another measures of money to output or prices began to break down (in the United States this process started in the mid 1970 s but became much more pronounced in the 1980s), a typical claim was that although the underlying theory remained valid as before, developments like financial innovation and deregulation had made the conventional $M$ 's no longer representative of the "money" that the theory intended. In other words, even "money" had become unobservable. 12

Market non-clearing presents yet further conceptual difficulties for the observability of both prices and quantities. While nobody has seriously suggested that bank deposit markets do not clear, problems of asymetric information and moral hazard do create this possibility in loan markets. Much of the research that associates real effects of monetary policy with the asset-holding rather than the liability-issuing aspect of what banks do makes no presumption that the credit market fails to clear, but models relying at least in part on lenders' rationing of credit have also played a prominent role in this line of research. ${ }^{13}$ If the market does not clear, neither the observed volume of credit extended nor the observed interest rate charged provides an adequate measure of the market's response to central bank actions. The quantity of credit that borrowers seek but are denied, and/or the interest rate at which the credit market would clear (or, equivalently, the shadow price of the rationing constraint), are also relevant. Both are fundamentally unobservable.

Identification (1). Even if all of the theoretically relevant prices and quantities were readily observable, empirical inference about monetary policy would still be problematic because of the difficulty of distinguishing central bank actions from their origins and consequences. Identification is a familiar 
problem in econometrics, and it arises in the monetary policy literature in two distinct ways.

First, as the example of the credit market (with or without non-clearing) immediately suggests, the usual problem of distinguishing supply and demand is central to any analysis of monetary policy. The central bank has a monopoly over the supply of bank reserves. Changes in the quantity of reserves, therefore, are unambiguously a matter of actions that the central bank can choose to take or not. ${ }^{14}$ But to the extent that the "right" measure of monetary policy is some different quantity - e either money or credit, for example - - the quantity observed in that market is jointly determined by banks' supply and their customers' demand. The central bank can influence banks' supply of money and credit by altering the supply of reserves, but the observed quantity nonetheless depends on other influences on bank behavior as well as on the entire constellation of factors influencing market demands.

Identification under these circumstances is therefore a matter of what the central bank can do as well as what it chooses to do. ("Policy," after all, does connote positive intent.) For example, when the relevant behavior is subject to lags, it may simply be impossible for the central bank to make the actual quantity of money or credit equal to some specific magnitude within a given time. No change in reserves, no matter how large, would be sufficient. In a more general context, the central bank may in principle be able to alter the supply of reserves sufficiently to offset any given disturbance to the market's demand for or banks' supply of money and credit, but it may choose not to do so if other objectives - most commonly, interest rate smoothing -. are also a consideration. Enpirically plausible values of the relevant demand and supply elasticities imply that extremely wide fluctuations in market interest rates (which the central bank could induce by comparably wide fluctuations in 
reserves supply) would be required to offset even fairly commonplace disturbances within short time periods like a month or a calendar quarter.

One potentially appealing approach to solving this problem would be to carry out empirical analysis of monetary policy within a longer period of time aggregation (a half-year, or a year, or even longer) .. long enough that the central bank plausibly could offset market disturbances to money and credit quantities within such time if it chose to do so. Still, problems remain. Wholly apart from questions of whether grosser units of time aggregation are adequate for investigating the real economic behavior that may be responding to monetary policy, it is still necessary to know (on what basis?) what the central bank actually seeks to do. The mere fact that the central bank can approximately offset disturbances to money or credit within a given time frame does not mean that it actually does so. Moreover, unless the relevant sources of stochastic variation happen to be closely correlated (and experience strongly suggests they are not), the central bank can at most offset the disturbances affecting one measure of either money or credit. Hence it is also necessary to know which specific $M$, or which concept of credit, is the focus of the central bank's policy.

An alternative approach is to represent monetary policy not by any quantity variable but by whatever interest rate represents the appropriate relative price in the market for bank reserves. In principle, the central bank can set this interest rate by using its monopoly power to supply reserves perfectly elastically at that relative price. Issues of supply-demand identification would not then arise. The problematic questions that remain, however, are whether the central bank can simply fix this interest rate, and whether it actually does so. The plausibility of the central bank's arbitrarily fixing any nominal interest rate is greater the shorter is the time 
horizon in question, and so representing monetary policy by an interest rate creates a presumption in favor of a shorter unit of time aggregation. Whether any specific central bank actually makes monetary policy in this way is, of course, a factual matter.

Representing monetary policy by an exchange rate is conceptually analogous, although the specifics of course differ at a practical level. The key questions are whether the central bank can fix its exchange rate, and whether it actually does so. As the problems experienced by several European countries in the early 1990s dramatically illustrated, simply assuming that observed exchange rate movements represent deliberate policy actions chosen by the central bank often misses the point of what actual policy is all about in a setting where exchange rates are central.

Identification (2). The second major sense in which problems of identification obscure analysis of monetary policy is that central bank actions, whether conceived in terms of a quantity or an interest rate or an exchange rate, depend on what is happening to nonfinancial activity and prices. After all, the point of having a monetary policy in the first place is to affect the trajectory of prices and real activity. ${ }^{15}$ Ample evidence on monetary policy "reaction functions" shows that central banks regularly ease monetary policy (however measured) in response to declines in output and employment and tighten policy in response to increases in inflation. (Central banks pursuing strict exchange rate objectives cannot vary monetary policy in this way, of course, but an exchange rate target implies an analogous set of responses to what is happening to real activity and prices.) The question of whether monetary policy affects real economic activity is therefore again a question about one side of a two-way interaction. 
The fact that monetary policy is itself part of an interactive process is problematic in several ways. Most obviously, as Sims (1972) first pointed out, it is therefore necessary to base econometric inferences about the effects of monetary policy not on the actual movements of chosen monetary policy variables (as in Friedman and Schwartz's work and countless related investigations) but only on that part of these variables' movement that is not systematically related to prior movements of the supposedly affected variables like output and prices. Sims showed how to make this principle empirically operational, using vector autoregressions, but conceptual issues still remain. Most obviously, even in vector autoregression form this methodology (like Friedman and Schwartz's) still bases inferences about what affects what entirely on matters of what precedes what - thereby running the risk of reaching a false positive conclusion through what Tobin (1970) called the "post hoc ergo propter hoc" fallacy. 16

At the same time, the vector autoregression methodology also risks arriving at false negative conclusions. For example, what if the central bank's behavior consisted entirely of systematic responses to observed movements of output, prices and other such variables? Monetary policy might still have real effects, and if the rule that the central bank followed were a good one, its actions would serve the intended purpose of damping fluctuations in real activity and/or inflation. But these effects would be impossible to detect. Given the vector autoregression methodology, evidence of their existence can come only from deviations from the central bank's normal responses - - that is, from times when the central bank tightens or eases monetary policy either more or less than what observed movements of output and prices would ordinarily warrant. But it is plausible to suppose there is usually some reason for the central bank's making policy tighter or easier than 
output and price movements warrant, and the larger is the deviation of policy from the ordinary, the greater is the presumption that there might well be some motivating circumstance behind it. If whatever is causing the central bank to behave in this aberrant way is also exerting an effect on, say, output, then the standard empirical procedures will fail to measure correctly the effect on output due to monetary policy.

Here again, a specific example may usefully illustrate the general principle at work. Taylor (1993a) has shown that U.S. monetary policy since 1987 has approximately followed a rule relating the federal funds rate (the overnight inter-bank lending rate in the United States) to observed fluctuations in inflation and real output. 17 But of course monetary policy has not been entirely regular in this way. Among the significant departures, one of the most visible was the $3 / 4$ percentage point reduction of the federal funds rate in late 1987. From the perspective of the econometrician estimating a "reaction function" relating short-term interest rates to inflation and output only, this action constituted precisely the kind of deviation that enables the standard empirical methodology to draw inferences about the effects of monetary policy. As was clear even at the time, however - and as official accounts also made explicit .- in this case the Federal Reserve was responding to the stock market crash in October of that year, out of concern that the fall in stock prices might depress subsequent real economic activity. The Federal Reserve's action was a deviation from the rule not because it represented surprising behavior under the circumstances but simply because the rule, as estimated, excludes fluctuations in stock prices as an independent variable to which the central bank might at times respond.

The importance of this distinction is that if the central bank makes monetary policy tighter or easier than normal not at random because it is 
seeking to offset some disturbance (not captured by other variables in the regression system) that it correctly foresees will affect output, then the usual regression procedures will under-estimate the effect on output due to monetary policy. ${ }^{18}$ In the example from the Taylor rule, even if the easing of monetary policy significantly increased the level of real output compared to what it otherwise would have been, observed output presumably did not fully reflect this increase because it was reduced by the contractionary effect of the stock market crash. In the limit, if the only reason the central bank ever departed from its usual response to prior movements of output and prices (or whatever else is in the econometrician's equation) were to offset the effect on output due to disturbances that it foresaw, and if - miraculously - - it were always exactly successful in offsetting these disturbances, then the evidence as interpreted by the vector autoregression would imply that monetary policy has no effect on output whatsoever.

Worse yet, if the central bank correctly foresaw disturbances to output but chose to offset them only in part -. as standard theory shows is optimal in the presence of uncertainty - - then observed output would be systematically lower in the aftermath of policy easing and higher after tightening, and the usual regression would even imply the wrong sign for the effect on output due to monetary policy. 


\section{Evidence}

Faced with these difficult challenges, at both the practical and the conceptual levels, empirical research on the real effects of monetary policy has followed three more or less distinct avenues.

Structural Models. First, a long-standing tradition of empirical research has taken a partial equilibrium approach to examining specific aspects of economic behavior that theory suggests may plausibly constitute key links between monetary policy actions and aggregate real activity: the interest elasticity of consumption and investment, the exchange rate elasticity of imports and exports, the dependence of consumption on real balances and other forms of wealth, effects of credit availability (however measured) on investment, and so on. Although specific results have varied widely - it would be astonishing if they did not, given the wide range of models and estimation methodologies that different researchers have used - the evidence provided by this line of research has broadly supported the idea that ample aspects of real economic behavior are sufficiently responsive to financial relative prices to create sizeable effects of monetary policy on aggregate activity. 19

A logical extension of this line of research is to bring together specific representations of consumption, investment, net exports and other elements of economic activity to provide estimates of the resulting effects of monetary policy on their aggregate. Here too, on the whole the evidence has mostly indicated sizeable real effects. The most widely known model of this kind, initially developed by the Federal Reserve System in conjunction with numerous academic researchers under the leadership of Modigliani and Ando, has consistently pointed to wealth effects on consumption, interest rate effects on firms' investment in plant and equipment, and both interest rate and credit 
rationing effects on residential investment, as major vehicles of monetary policy effects on real economic activity in the United States. More recent versions have likewise indicated substantial exchange rate effects on net exports. ${ }^{20}$ Fair $(1976,1984,1994)$ and Taylor (1993b), among others, have developed econometric models with the same intended purpose but, importantly, based on quite different empirical methodologies. Their models also indicate sizeable real effects of systematic monetary policy, again operating through familiar elements of economic behavior like consumption, investment and net exports. (Taylor's model is especially interesting in that it provides such evidence for each of the G-7 countries.)

The main criticisms of this line of research, for purposes of its bearing on monetary policy, are that the a priori restrictions imposed in specifying the individual behavioral relationships artificially exaggerate the crucial elasticities and that, even if the individual elements of real economic behavior are as responsive to financial relative prices as the evidence from these models suggests, the models when assembled into statements about general equilibrium do not satisfactorily identify movements in those financial relative prices as consequences of monetary policy. Both lines of argument criticisms have generated substantial discussion. 21 In part because of these criticisms, but perhaps even more so as a result of economists' preference for simplicity (see again Section I), evidence from this kind of structural analysis of individual elements of economic behavior, either taken in isolation or integrated into comprehensive models, has played only a limited role in recent debate over whether monetary policy has real effects. (By contrast, evidence from these models has been widely used to quantify the effects of monetary policy, given the prior assumption that they do exist.) 
Vector Autoregressions. The second major avenue of empirical research on whether monetary policy affects real economic activity has followed Friedman and Schwartz (1963) in eschewing explicit representations of economic behavior and instead focusing directly on the observed comovement between some variable taken to represent monetary policy and some aggregate measure of real activity. Following Sims, the principal vehicle of analysis for this purpose has been the vector autoregression. The volume of this work is far too great, and the results too diverse, to permit a comprehensive survey here. 22

Although most of this work has produced results consistent with significant real effects of monetary policy, these results have not proved fully conclusive, largely as a result of various manifestations of the problems of identification and observability discussed in Section II. More generally, as Sims' own work has highlighted, whether a vector autoregression implies that any particular variable has predictive content with respect to any other can change dramatically when the set of additional variables included in the regression system changes.

Following Friedman and Schwartz, empirical work in this vein at first mostly used one or another monetary quantity as the chosen measure of monetary policy. Progressive research contributions increasingly called this assumption into question, however. Sims (1980) showed that when the regression system included an interest rate, the interest rate had predictive content with respect to output but money did not. ${ }^{23}$ King and Plosser (1984) argued, on the basis of conceptually similar evidence, that output evolves independently of monetary policy (as the "real business cycle" model implies) and that fluctuations in money anticipate fluctuations in output only because of the role of money in production. Bernanke (1986) argued instead for a "credit view" according to which monetary policy does affect real activity but the 
"right" quantity for gauging monetary policy is not money but credit. In this model, the predictive content of money with respect to output arises as a consequence of the structure of the banking system, which renders money and credit correlated. The main import of each of these contributions (and many others that were similar) was to question whether the repeated finding that monetary quantities conditionally predicted output in vector autoregressions legitimately constituted evidence that monetary policy had real effects. Tobin's "post hoc ergo propter hoc" criticism had assumed center stage.

As this line of research was proceeding, however, the empirical relationship for which researchers were debating different explanations itself disappeared. By the mid to late 1980 s, standard relationships connecting money to output had collapsed in the United States and had deteriorated in many other countries as well. Worse yet, at least in the United States, the statistical relationship between money and prices had collapsed also. 24 Wholly apart from the question of real effects, therefore, to continue to use the conventional M's as measures of monetary policy was to accept the unlikely idea that monetary policy did not even affect inflation.

Moreover, as the collapse of money-income and even money-price relationships became more widely recognized, it became less plausible to suppose that central banks themselves continued to make actual monetary policy in terms of monetary aggregates. In time some central banks, like the U.S. Federal Reserve System, formally acknowledged that they no longer relied on monetary aggregates in this way. Other central banks continued to insist that they did so, even though in some cases their actions suggested otherwise.

Especially in light of what increasingly seemed to be actual central bank practice, the most plausible alternative for countries that do not have explicit exchange rate targets was to discard quantity variables as measures of 
monetary policy and focus instead on short-term interest rates. Bernanke and Blinder (1992) presented two kinds of evidence for the United States suggesting that the federal funds rate (or more precisely, given the vector autoregression methodology, the innovation to the federal funds rate) is a satisfactory measure of monetary policy. First, during the intervals between meetings of the Federal Open Market Committee, the Federal Reserve's key policymaking group for purposes of monetary policy, the supply of nonborrowed reserves is indeed highly elastic (see again the discussion in Section II). Second, as Taylor's (1993a) work also showed, the systematic response of the federal funds rate to prior fluctuations in inflation and unemployment has followed a pattern consistent with a conventional "monetary policy reaction function."

On the ultimate question of whether monetary policy has real effects, Bernanke and Blinder showed that the federal funds rate does have predictive content with respect to a wide variety of measures of real economic activity (production, employment, sales, consumption, housing starts, durable goods orders, and so on). Following their work, numerous other researchers have likewise adopted a short-term interest rate as the relevant measure of monetary policy in whatever country is under study. More recently, Bacchetta and Ballabriga (1995) have provided evidence, based on responses of banks' assets and liabilities, supporting the use of a short-term interest rate as a monetary policy measure in thirteen European countries and indicating systematic effects on output in ten of the thirteen. 25

While these findings based on short-term interest rates as measures of monetary policy appear to make consistent sense from the perspective of monetary policy effects on output, reconciling the inferred policy movements with subsequent fluctuations in prices has been less straightforward. Sims (1992) showed that, in each of the G-5 countries, increases in the selected 
short-term interest rate systematically anticipate negative movements of output but also systematically anticipate positive movements of prices. ${ }^{26}$ This "price puzzle" therefore cast doubt on whether the negative relationship to output was genuine evidence of an effect of monetary policy on real activity or merely a statistical artifact -. a manifestation of the Tobin problem .. attributable to some other factor.

As Christiano, Eichenbaum and Evans (1994) demonstrated, however, at least for the United States it is the "price puzzle" itself that appears to be this kind of artifact, for just the reason suggested in Section II. In particular, if the central bank has information indicating that prices are going to rise and tightens monetary policy so as partially to offset this increase, then prices rise anyway after a policy tightening, and a regression that excludes this source of information will estimate the wrong sign for the effect of monetary policy on prices.

The most obvious observable source of information about shocks to prices during the sample period used in most recent empirical analyses of monetary policy has been the changing price of raw commodities, especially including oil. Crude oil prices rose sharply in 1973 and again in 1979, following actions by the OPEC cartel to restrict supply, only to fall back equally sharply in the mid 1980 s as the cartel ceased to be economically viable. For central banks to have varied monetary policy so as only partially to offset the effect of oil price changes on overall price movements would have made sense not only on the usual grounds of optimal policymaking under uncertainty but also because of the effect of such "supply shocks" on output and employment. 27 Christiano et al. showed that if the regression system not only includes an index of commodity prices (as Sims' did) but also orders this index ahead of the monetary policy variable (so as to capture monetary policy 
responses to $i t)$, then the "price puzzle" disappears in that higher short-term interest rates have no significant effect on overall prices for some time and then a negative effect -- as is consistent with conventional interpretations of the negative effect on output. 28

Prices, of course, are not the only variable other than real output that it makes sense to examine for this kind of consistency. Indeed, to the extent that tests for effects of monetary policy focus on variables other than output and prices (and their immediate derivatives like employment), which are the principal focus of central banks' monetary policy objectives, the identification problem associated with feedback responses is lessened. Grilli and Roubini (1995) showed that, in all G-7 countries other than the United States, vector autoregressions including the usual set of variables plus an exchange rate indicate that the exchange rate systematically depreciates after the central bank tightens monetary policy (measured, again, by interest rate innovations). 29 Although each country's currency depreciates only briefly after a tightening of monetary policy, the subsequent appreciation is sufficiently slow and limited that for most countries the overall effect is a persistent depreciation.

Grilli and Roubini concluded, however, that this "exchange rate puzzle" is yet another example of misleading inference drawn from a vector autoregression that excludes information to which central banks actually respond. The counter-intuitive exchange rate response mostly disappears when the regression system for each non-U.S. country includes not only the U.S. federal funds rate (as a measure of U.S. monetary policy) but also the difference between longand short-term interest rates in that specific country (as a measure of that country's expected inflation, in the spirit of Christiano et al.). With the "exchange rate puzzle" thus more or less resolved, Grilli and Roubini also 
confirmed the usual negative effect on each country's output following a tightening of its own monetary policy.

In sum, while problems of identification and observability continue to plague the application of vector autoregression methods to questions about monetary policy, the major challenges that various researchers have mounted to this line of work have not proved insuperable. Moreover, the overall results have provided fairly consistent evidence that, whatever other contradictions may arise, variables like short-term interest rates, which can plausibly be associated with central bank actions, do systematically anticipate movements in real economic activity. ${ }^{30}$ Apart from the dependence of the entire vector autoregression methodology on "post hoc ergo ergo propter hoc" inference, the lingering question about this evidence, at the broadest conceptual level, is simply one of ultimate identification: Given the large number of variables that are of potential relevance, compared to the practical limitations on what an operational regression system can contain, perhaps it is always possible to find some set of variables which, when included, can deliver any desired empirical finding. Except with the passage of time, there is no way to resolve this question within the vector autoregression methodology itself.

Non-quantitative Information. Finally, the third major line of empirical research in recent years on the real effects of monetary policy has centered on the use of data from non-quantitative sources. In large part in response to just the kind of unanswerable questions raised above about both the vector autoregression approach and the partial equilibrium approach, Romer and Romer (1989) introduced a formal role for non-quantitative information as a supplement to the usual quantitative data. There was (and is), of course, a long-standing tradition of relying on non-quantitative evidence in monetary economics, but mostly in informal ways. ${ }^{31}$ Romer and Romer's methodological 
innovation was to recast the relevant non-quantifiable information in quantitative form and thereby render it usable, along with conventional time series data, in formal hypothesis testing.

The specific problem that Romer and Romer sought to resolve by using non-quantitative information is the identification of the central bank's monetary policy actions. Rather than implicitly inferring these actions from observed monetary and credit quantities, or financial relative prices, Romer and Romer explicitly identified six episodes of independent monetary policy tightening by studying the minutes and published policy records of the Federal Reserve Board of Governors and the Federal Open Market Committee in the post World War II period through $1987 .{ }^{32}$ They then represented this information by a zero/one time series, which they used as an independent variable in conventional regressions for output and unemployment. Their results indicated that output systematically falls, and unemployment systematically rises, after the Federal Reserve tightens monetary policy. The time series for the "Romer dates" has subsequently become a standard variable to include in empirical investigations of U.S. monetary policy.

Introducing non-quantitative information in this way can help to identify the monetary policy actions whose effects are the ultimate issue in question, but only to the extent that the non-quantitative data (like minutes and policy records of key meetings) themselves admit unambiguous inferences. The challenge confronting Romer and Romer's use of such materials was especially great because their objective was to establish episodes when the Federal Reserve tightened monetary policy for reasons other than in response to what was happening to real economic activity. ${ }^{33}$ They therefore had to infer not only when the Federal Reserve tightened policy but why. Judging intent nearly always involves ambiguity. Moreover, even if non-quantitative information does 
satisfactorily identify the relevant time series to represent monetary policy, substituting one time series for another does not address the reliance of the underlying vector autoregression methodology on "post hoc ergo propter hoc" evidence. Not surprisingly, Romer and Romer's findings have attracted criticism along both lines of argument. 34

Because of the time-consuming effort involved in interpreting central bank minutes and policy reports, there is to date little work along these lines for countries other than the United States. One current example, however, likewise indicates significant effects of monetary policy on real economic activity. Tsatsaronis (1993) used the Deutsche Bundesbank's published monthly reports for 1957-90 to identify five episodes of independent tightening of German monetary policy. In parallel to Romer and Romer's findings, his results showed that German industrial production and employment systematically declined after monetary policy tightening. 


\section{In Conclusion}

Where, then, does all this leave central bankers and others who need to know whether monetary policy affects real economic activity or not? The predominant weight of the existing evidence, assembled using each of three different empirical methodologies -- partial equilibrium structural models, vector autoregressions based on observed prices and quantities, and vector autoregressions incorporating non-quantitative information -. suggests that the real effects of monetary policy are systematic, significant, and sizeable. Yet questions remain, both about individual empirical results and about each methodological approach more broadly.

In all likelihood, such questions will always remain. Just as earlier research produced findings that new research questioned, only to have yet further research challenge these answers, the progressive interplay of empirical findings and subsequent questions is an ongoing process. It is a sign of the development of economics as an empirical science.

Importantly, however, the process is progressive, not merely circular. We may not yet satisfactorily "know" whether monetary policy affects real economic activity, but as a result of the research summarized here we do know more than we did. And what we have learned mostly buttresses what we "knew" - - in a different sense -- before. Monetary policy does have systematic real effects, and they are both statistically significant and economically important. 
*This paper was prepared for a conference on "Monetary Policy in an Integrated World Economy" at the Kiel Institute of World Economics, June 21-22, 1995. I am grateful to Fernando Leforte for research assistance, to numerous friends and colleagues for useful suggestions, to John Taylor and other participants in the Kiel Institute conference for helpful comments on an earlier draft, and to the G.E. Foundation and the Harvard Program for Financial Research for research support.

1. A wholly different reason for preferring simple models is a belief, which parallels a view more frequently encountered in sciences like particle physics, that reality itself must be elegant and therefore simple.

2. Keynes (1936), p. 378 .

3. See, for example, Fischer (1993). Bruno and Easterly (1995), however, have argued that even these findings are a reflection of relatively short-lived "inflation crises."

4. Such ideas may perhaps become more acceptable if chaos theory continues to exert a growing impact on the sciences. But economics as we know it is very much a product of the Enlightenment, which was itself an expression of optimism grounded in the possibilities of science, and therefore philosophically inhospitable to the idea of permanently lost opportunities and irredeemable errors.

5. Taylor's (1980) model of staggered multi-period wage setting usefully extended this basic idea. See Fuhrer and Moore (1995) for more recent work extending it further. An important feature of this entire line of analysis is to combine finite-period price stickiness with forward-looking expectations, thereby allowing "credibility effects" to play a role in the real effects of monetary policy.

6. Further lines of thinking that exhibit these same general properties are models based on "real rigidities" (e.g., Ball and Romer 1990) and models based on "coordination failures" (e.g., Blanchard and Kiyotaki 1987).

7. It is always possible to resolve this dilemma by arguing that monetary policy does have real effects but that they are also very small. But in that case the whole enterprise is of questionable importance.

8. Total reserves of U.S. banks were $\$ 59$ billion at yearend 1994 .

9. The discussion here abstracts from the existence of currency, and hence also from the distinction between reserves and the monetary base. (In the United States, the Federal Reserve has always elastically accommodated the public's demand for currency.) 
10. Examples of research along each of these lines include Moore et al. (1990), Kashyap et al. (1993), Stiglitz and Weiss (1981) and Gertler and Gilchrist (1994).

11. In principle, a market for indexed bonds would admit direct observation of a real interest rate, but even then there would be questions about whether the rate observed in this market is the relevant rate for analyzing the particular behavior in question. (For example, if the issuer is the government it is necessary to infer the corresponding rate for private credits. Complications due to tax considerations are another example.) For a recent analysis of the British experience with indexed government debt, see Barr and Pesaran (1995).

12. The Federal Reserve System's repeated redefinition of the M's was motivated by this view, as is the more recent line of research pursued by Rotemberg et al. (1995) and Feldstein and Stock (1994), for example. It is worth remembering that the many changes in the official definition's should have made today's M's exhibit a closer relationship to output and prices, and so the failure of such relationships to obtain is all the more compelling.

13. See Friedman and Kuttner (1993b) for a discussion distinguishing market-clearing from non-clearing models within the "credit view" of monetary policy. For a survey of contributions to the "credit view" more generally, see Bernanke (1993).

14. Even this statement strictly applies only to nonborrowed reserves, and only then to nonborrowed reserves after adjustment for such factors as float, currency movements and the like.

15. There are other reasons for having a central bank, but they do not imply a need for "monetary policy" as it is commonly understood.

16. For more formal discussions of the limitations of the vector autoregression methodology in this context, see, for example, Zellner (1979, 1988), Leamer (1985) and Cagan (1989).

17. Interestingly, Taylor's analysis also shows that the specifics of the Federal Reserve's apparent rule, including its quantitative responses, are approximately optimal for purposes of minimizing the long-run variances of inflation and real activity.

18. This point is an old one in the literature of economic policy literature. See, for example, Goldfeld and Blinder (1973) and, more recently, Poole (1994).

19. See, for example, the numerous studies listed in surveys by Chouraqui et al. (1988), Abel (1990), Jaffee and Stiglitz (1990) and Bernanke (1993). See also the summary estimates by Akhtar and Harris (1987) and Friedman (1989).

20. The earliest systematic presentation of this model was by de Leeuw and Gramlich $(1968,1969)$. For a more recent version, see Brayton and Mauskopf (1985). 
21. For a recent defense of structural models, see Fair and Shiller (1990).

22. See, for example, the surveys by Chouraqui et a1. (1988), Cagan (1989) and Blanchard (1990), as well as the numerous more recent references cited by Cochrane (1994) and Grilli and Roubini (1995).

23. Stock and Watson (1989), among others, argued that also including a time trend in the regression restored the predictive content of money in the presence of an interest rate, but Friedman and Kuttner (1993a) showed that even this result depended on the use of a specific interest rate. (In line with the discussion below, Stock and Watson's result also disappeared when the sample was extended).

24. See, for example, Friedman and Kuttner (1992).

25. See also the earlier empirical results for numerous countries in Chouraqui et. al (1988).

26. In Sims' results an initially positive price response is consistent across all five countries, but the positive response is large and persistent in only two (France and Japan).

27. See, for example, Aizenmann and Frenkel's (1986) analysis of optimal monetary policy response to supply shocks.

28. Another difference is that Christiano et al. used the GDP deflator as the measure of overall prices, in contrast to Sims' use of the consumer price index. They also carried out their analysis using nonborrowed reserves as a measure of monetary policy, in addition to the federal funds rate, and found highly similar results in the two systems. See also Christiano et al. (1995) and Sims and Zhou (1993).

29. Eichenbaum and Evans (1993) had previously shown that the exchange rate response has the anticipated sign in the United States.

30. Other interesting recent work in this vein using data not just for the United States includes Evans and Santos (1993), Gerlach and Smets (1994) and Skinner and Zettelmeyer (1994). Each of these papers provides a distinct conceptual extension to the work described above.

31. The most obvious early example is Adam Smith's lengthy "Digression concerning the Variations in the Value of Silver during the Course of the Four Last Centuries" in The Wealth of Nations. The example most familiar to economists today is presumably Friedman and Schwartz (1963).

32. They did not identify episodes of policy easing. In subsequent work, Romer and Romer (1994) identified a seventh policy tightening, in 1988.

33. Their objective was conceptually identical to that of a vector autoregression: to isolate movements in monetary policy that were not predictable on the basis of prior movements in the variables on which they were then to test for monetary policy effects. This is precisely what a vector autoregression does in focusing on a variable's innovations.

34. On the "post hoc ergo propter hoc" issue, for example, see Hoover and Perez (1994). 


\section{References}

Abe1, A. B. (1990). Consumption and Investment. In B. M. Friedman and F. Hahn (eds.), Handbook of Monetary Economics. Amsterdam: North-Holland.

Aizenmann, J., and J. A. Frenkel (1986). Supply Shocks, Wage Indexation, and Optimal Monetary Policy. Journal of Money, Credit and Banking 18: $304-322$.

Akerlof, G. A., and J. L. Yellen (1985). A Near-Rational Model of the Business Cycle, with Wage and Price Inertia. Quarterly Journal of Economics 100: $823-838$.

Akhtar, M. A., and E. S. Harris (1987). Monetary Policy Influence on the Economy -- An Empirical Analysis. Federal Reserve Bank of New York, Quarterly Review 19-34.

Bacchetta, P., and F. Ballabriga (1995). The Impact of Monetary Policy and Bank Lending: Some International Evidence. Mimeo. Swiss National Bank.

Bal1, L., and Romer, D. (1990). Real Rigidities and the Nonneutrality of Money. Review of Economic Studies 57: 183-203.

Barr, D. G., and B. Pesaran (1995). An Assessment of the Relative Importance of Real Interest Rates, Inflation and Term Premia in Determining the Prices of Real and Nominal U. K. Bonds. Mimeo. Bank of England.

Bernanke, B. S. (1993). Credit in the Macroeconomy. Federal Reserve Bank of New York, Quarterly Review 18: $50-70$.

Bernanke, B. S. (1986). Alternative Explanations of the Money-Income Correlation. Carnegie-Rochester Series on Public Policy 25: 51-68.

Bernanke, B. S., and A. S. Blinder (1992). The Federal Funds Rate and the Channels of Monetary Transmission. American Economic Review 79: 14-31.

Bernanke, B. S., and M. Gertler (1986). Agency Costs, Collateral, and Business Fluctuations. American Economic Review 79: 14-31.

Blanchard, O. J. (1990). Why Does Money Affect Output? A Survey. In B. M. Friedman and F. Hahn (eds.), Handbook of Monetary Economics. Amsterdam: North-Holland.

Blanchard, O. J., and N. Kiyotaki (1987). Monopolistic Competition and the Effects of Aggregate Demand. American Economic Review 77: 647-666.

Brayton, F., and E. Mauskopf (1985). The Federal Reserve Board - MPS Quarterly Econometric Model of the U. S. Economy. Economic Modelling 2: 170-292. 
Bruno, M., and W. Easterly (1995). Inflation Crises and Long-Run Growth. Mimeo. World Bank.

Cagan, P. (1989). Money-Income Causality - A Critical Review of Literature Since Monetary History. In M. D. Bordo (ed.), Money, History, and International Finance. Chicago: University of Chicago Press.

Caplin, A., and D. F. Spulber (1987). Menu Costs and the Neutrality of Money. Quarterly Journal of Economics 102: 703-726.

Chouraqui, J.-C., M. Driscoll, and M.-0. Strauss-Kahn (1988). The Effects of Monetary Policy on the Real Sector: An Overview of Empirical Evidence for Selected OECD Economics. Mimeo. OECD.

Christiano, L. J., M. Eichenbaum, and C. Evans (1994). The Effects of Monetary Policy Shocks: Some Evidence from the Flow of Funds. Mimeo. NBER.

Christiano, L. J., M. Eichenbaum, and C. L. Evans (1995). Identification and the Effects of Monetary Policy Shocks. In M. Blejer et al. (eds.), Financial Factors in Economic Stabilization and Growth. Cambridge: Cambridge University Press, forthcoming.

Cochrane, J. H. (1994). Shocks. Carnegie-Rochester Conference Series on Public Policy 41: 295-364.

Deleeuw, F., and E. Gramlich (1968). The Federal Reserve - MIT Econometric Mode1. Federal Reserve Bulletin 54: $11-40$.

DeLeeuw, F., and E. Gramlich (1969). The Channels of Monetary Policy. Federal Reserve Bulletin 55: 472-491.

Eichenbaum, M., and C. Evans (1993). Some Empirical Evidence on the Effects of Monetary Policy Shocks on Exchange Rates. Mimeo. NBER.

Evans, C. L., and F. Santos (1993). Monetary Policy Shocks and Productivity Measures in the G-7 Countries. Mimeo. Federal Reserve Bank of Chicago.

Fair, R. C. (1976). A Model of Macroeconomic Activity: The Empirical Model Cambridge: Ballinger.

Fair, R. C. (1984). Specification, Estimation, and Analysis of Macroeconometric Models. Cambridge: Harvard University Press.

Fair, R. C. (1994). Testing Macroeconometric Models. Cambridge: Harvard University Press.

Fair, R. C., and R. J. Shiller (1990). Comparing Information in Forecasts from Econometric Models. American Economic Review 80: 375-389.

Feldstein, M., and J. H. Stock (1994). Changing the Definition of a Monetary Aggregate in the Presence of Financial Innovation. Mimeo. NBER.

Fischer, S. (1977). Long-Term Contracts, Rational Expectations, and the Optimal Money Supply Rule. Journal of Political Economy 85: 191-206. 
Fischer, S. (1993). The Role of Macroeconomic Factors in Growth. Journal of Monetary Economics 32: 485-512.

Friedman, B. M. (1989). Changing Effects of Monetary Policy on Real Economic Activity. In Monetary Policy Issues in the 1990s. Kansas City: Federal Reserve Bank of Kansas City.

Friedman, B. M., and K. N. Kuttner (1992). Money, Income, Prices and Interest Rates. American Economic Review, 82: $472-492$.

Friedman, B. M., and K. N. Kuttner (1993a). Another Look at the Evidence on Money-Income Causality. Journal of Econometrics 57: 189-203.

Friedman, B. M., and K. N. Kuttner (1993b). Economic Activity and the Short-Term Credit Markets: An Analys is of Prices and Quantities. Brookings Papers on Economic Activity 193-266.

Friedman, M., and A. J. Schwartz (1963). A Monetary History of the United States 1867-1960. Princeton: Princeton University Press.

Fuhrer, J., and G. Moore (1995). Inflation Persistence. Quarterly Journal of Economics 110: 127-159.

Gerlach, S., and F. Smets (1994). The Monetary Transmission Mechanism: Evidence from the G.7 Countries. Mimeo. Bank for International Settlements.

Gertler, M., and S. Gilchrist (1994). Monetary Policy, Business Cycles and the Behavior of Small Manufacturing Firms. Quarterly Journal of Economics, 109: $310-339$.

Goldfeld, S. M., and A. S. Blinder (1973). Some Implications of Endogenous Stabilization Policy. Brookings Papers on Economic Activity 585-640.

Grilli, V., and N. Roubini (1995). Liquidity and Exchange Rates: Puzzling Evidence from the G-7 Countries. Mimeo: Yale University.

Hoover, K. D., and S. J. Perez (1994). Post Hoc Ergo Propter Hoc Once More: An Evaluation of 'Does Monetary Policy Matter' in the Spirit of James Tobin. Journal of Monetary Economics 34: 47-73.

Jaffee, D., and J. Stiglitz (1990). Credit Rationing. In B. M. Friedman and F. Hahn (eds.) Handbook of Monetary Economics. Amsterdam: North-Holland.

Kashyap, A. K., J. C. Stein, and D. W. Wilcox (1993). Monetary Policy and Credit Conditions: Evidence from the Composition of External Finance. American Economic Review 83: 78-98.

Keynes, J. M. (1936). The General Theory of Employment Interest and Money. New York: Harcourt Brace \& World.

Leamer, E. E. (1985). Vector Autoregressions for Causal Inference? Carnegie-Rochester Conference Series on Public Policy 22: 255-303. 
Mankiw, N. G. (1985). Small Menu Costs and Large Business Cycles:

A Macroeconomic Model of Monopoly. Quarterly Journal of Economics 100: $529-539$.

Moore, G. R., R. D. Porter, and D. H. Small (1990). Modeling the Disaggregated Demands for $M 2$ and M1: The U. S. Experience in the 1980s. In P. Hooper et al. (eds.), Financial Sectors in Open Economies: Empirical Analysis and Pollcy Issues. Washington: Board of Governors of the Federal Reserve System.

Phelps, E. S., and J. B. Taylor (1977). Stabilizing Powers of Monetary Policy Under National Expectations. Journal of Political Economy 85: 163-190.

Poole, W. (1994). Monetary Aggregates Targeting in a Low-Inflation Economy. In J. C. Fuhrer (ed.), Goals, Guidelines, and Constraints Facing Monetary Policymakers. Boston: Federal Reserve Bank of Boston.

Romer, C. D., and D. H. Romer (1989). Does Monetary Policy Matter? A New Test in the Spirit of Friedman and Schwartz. NBER Macroeconomics Annual. Cambridge: MIT Press.

Romer, C. D., and D. H. Romer (1994). Monetary Policy Matters. Journal of Monetary Economics 34: 75-88.

Rotenberg, J. J., J. C. Driscoll, and J. M. Poterba (1995). Money, Output, and Prices: Evidence from a New Monetary Aggregate. Journal of Business and Economic Statistics 13: 67-83.

Sargent, T. J., and N. Wallace (1975). 'Rational' Expectations, the Optimal Monetary Instrument, and the Optimal Money Supply Rule. Journal of Political Economy 83: 241-254.

Sims, C. A. (1972). Money, Income, and Causality. American Economic Review 62: $540-552$.

Sims, C. A. (1980). Comparison of Interwar and Postwar Business Cycles: Monetarism Reconsidered. American Economic Review 70: 250-257.

Sims, C. A. (1992). Interpreting the Macroeconomic Time Series Facts: The Effects of Monetary Policy. European Economic Review 36: 975-1011.

Sims, C. A., and T. Zhou (1993). Does Monetary Policy Generate Recessions? Using Less Aggregated Price Data to Identify Monetary Policy. Mimeo. Yale University.

Skinner, T., and J. Zettelmeyer (1994). Long Rates and Monetary Policy: Is Europe Different? Mimeo. MIT.

Stiglitz, J. E., and A. Weiss (1981). Credit Rationing in Markets with Imperfect Information. American Economic Review 71: 393-410.

Stock, J. H., and M. W. Watson (1989). Interpreting the Evidence on Money-Income Causality. Journal of Econometrics 40: 161-182. 
Taylor, J. B. (1980). Aggregate Dynamics and Staggered Contracts. Journal of Political Economy 88: 1-24.

Taylor, J. B. (1993a). Discretion versus Policy Rules in Practice. CarnegieRochester Conference Series on Public Policy 39: 195-214.

Taylor, J. B. (1993b). Macroeconomic Policy in a World Economy: From Econometric Design to Practical Operation. New York: Norton.

Tobin, J. (1970). Money and Income: Post Hoc Ergo Propter Hoc? Quarterly Journal of Economics 82: 301-317.

Tsatsaronis, K. E. (1993). Bank Lending and the Monetary Transmission Mechanism: The Case of Germany. Mimeo. University of California, Berkeley.

Zellner, A. (1979). Causality and Econometrics. Carnegie-Rochester Conference Series on Public Policy 10: 9-54.

Zellner, A. (1988). Causality and Causal Laws in Economics. Journal of Econometrics 39: 7-22. 